\title{
Factors Related To Smoking Behaviour At Traditional Islamic Boarding School In Aceh Besar In 2018
}

\author{
Ismail $^{1,2 *}$, Teuku Tahlil ${ }^{3}$, Nurussalam ${ }^{4}$ dan Zurnila Marli Kesuma ${ }^{5}$ \\ \{ismail@gmail.com $\left.{ }^{1}\right\}$ \\ ${ }^{1}$ Doctoral Program in Mathematics and Application Sciences (DMAS) Syiah Kuala University; \\ *2 Nursing Department of Health Polytechnic Aceh Health Ministry; \\ ${ }^{3}$ Faculty of Nursing, Syiah Kuala University; \\ ${ }^{4}$ Faculty of Nursing, Airlangga University; \\ ${ }^{5}$ Faculty of Mathematics and Natural Science, Syiah Kuala University
}

\begin{abstract}
According to Regional Health Research data in 2013, Aceh has the highest percentage of smoking population with an average of 21-23 cigarettes per day $(9,9 \%)$. In addition, the prevalence of 16-19 years old smokers increased 3 times from $7.1 \%$ in 1995 to $20.5 \%$ in 2014. Beginner/new smokers aged 10-14 years increased by more than $100 \%$, from $8.9 \%$ in 1995 to $18 \%$ in 2013. [1] found that $36.6 \%$ of smokers in Aceh were graduated from elementary school and $37.8 \%$ did not complete elementary school. One of the factors is the public figure smoker. There has been various policy made in Aceh Besar such as the Regent's Regulation Number 40 of 2016 concerning a smokefree area and the fatwa (instruction) of the MUI commission that smoking is forbidden for children and in public areas. The purpose of this study is to find the factors associated with the smoking behaviour of students in Islamic traditional boarding school in Aceh Besar. This research is descriptive analytic with a cross-sectional study design. The population is students who are less than 21 years old, the number of samples is 71 people. Sampling was done by random sampling. Data analysis uses the Chi-Square test. The results of this study reveal that there is no relation between student's smoking behaviour and education and knowledge. However, there was a correlation between cigarette availability, regulation and the behaviour of smoker's friends with students' smoking behaviour in the Traditional Islamic Boarding School In Aceh Besar. For this reason, it is recommended that there must be a continuing counselling and a regulation on smoking in Islamic boarding schools. Moreover, the principal of Boarding school should set a good example for students.
\end{abstract}

Keywords: Smoking behaviour, Islamic Boarding School students

\section{Introduction}

During the mid-1990s, smoking was identified as a major cause of death and disability that could be prevented in developed countries. Around 3 million people were estimated to die from smoking each year and around 1.5 million died before the ages of 70 (1). Besides, the number of deaths due to smoking is estimated at 10 million per year by 2020 , and $70 \%$ of 
early deaths occurred in developing countries (2). Smoking is also responsible for six million deaths each year and this attracts great attention for social marketers (3). The attitude and behaviour of parents or families who smoke in front of their children encourage them to smoke in the future and consider smoking to be an act that does not violate the norm (4). According to social learning theory, children learn smoking behaviour from their surroundings. This opinion is supported by [2], (5), who assess the attitudes of parents on exposure of cigarette smoke on their children. If it is not prevented, the smoking behaviour among teenagers is feared to cause various social problems such as marijuana, alcohol, and other prohibited substances, there have been many studies proven that cigarette addiction is the gateway of drugs abuse such as heroin, marijuana, and other dangerous substances (6). Many aspects of tobacco use are controlled by culture. Cigarettes become symbolic in many traditions around the world. Society used to regard smoking as a symbol of friendliness and communication. Some cultures view smoking as a prestigious behaviour that results in personal satisfaction (7).

The number of active smokers in Aceh is as many as 29,7\%, even 10\% of 10-20 years old teenagers are registered as active smokers. Smoking not only affects health but also affects the socio-economic community. The Central Statistics Agency (BPS) noted that cigarettes contribute to a large share of poverty. For urban communities, $12.99 \%$ of the income is spent on cigarettes every month, while those who live in rural areas spent $11.39 \%$ for cigarettes (8).

The Regional Health Research Report (Riskesda) in 2013 found that the average number of cigarettes smoked per day by more than half (52.3\%) of smokers was 1-10 cigarettes. Aceh has the highest percentage of population smoking with an average of 21-23 cigarettes per day $(9,9 \%)$. In addition, based on the date from the Ministry of Health the prevalence of 16-19 years old smokers increased 3 times from $7.1 \%$ in 1995 to $20.5 \%$ in 2014. In addition, smokers aged 10-14 years (early age smokers) increased by more than $100 \%$ within 20 years, from $8.9 \%$ in 1995 to $18 \%$ in 2013 (9). Various efforts have been made both by the Puskesmas and the Aceh Besar Health Office. In term of regulation, it has become stricter since the launch of Regent's Regulation Number 40 of 2016 concerning a smoke-free area (10). Moreover, the decision of the MUI fatwa commission in 2003 which issued a fatwa on smoking, which at that time was limited to Makruh (not prohibited). However, in the MUI coordination meeting in Sumatra in Palembang in July 2008, it was decided that smoking was forbidden for pregnant women, children and in public areas. [1](11) found that $36.6 \%$ of smokers in Aceh were graduated from elementary school and $37.8 \%$ did not complete elementary school. In addition, one of the factors contributed to the smoking behaviours is the cultural/religious events and the public figure of such events is a smoker. Based on observation in one of the traditional Islamic boarding schools, there is no prohibition on smoking inside the school environment, cigarettes are sold freely, and the teacher and the principal of schools are also smokers. According to the students, anyone can smoke anywhere they want around the school environment. According to them, there is no organization has ever come to the boarding school to conduct counselling about cigarettes and smoking behaviour.

\section{Methodology Research}

There are many factors contributing to smoking behaviour among teenagers [3] in (12) revealed that the risk factors for smoking among adolescents are influenced by several factors including: 
1. Psychological or personality factors, it includes include stress, curiosity, boredom, masculinity, low self-esteem, and rebellion. Those are things that contribute to youth to start smoking. Moreover, psychologically smoking behaviour in adolescents is also associated with psychiatric disorders.

2. Biological factors, including cognitive functions, ethnicity, genetics and gender.

3. Environmental factors, including parents, siblings, peers and billboards or advertisements displaying the teen idol.

4. Regulatory factors, applying high taxes or customs duties on cigarettes in order to reduce the cigarettes consumption and limiting facilities or locations for smoking.

5. Smoking behaviour influenced by "negative feelings", people smoke to reduce negative feelings, for example if someone is angry, anxious, nervous, cigarettes are considered as saviour.

6. Addictive Smoking behaviour, also called the psychological addiction. Those who have been addicted will increase the dose of cigarettes whenever the effects of cigarettes are diminished.

7. Habitual Smoking behaviour, those who smoke as a habit. It can be said that these types of smokers are an automatic behaviour, often unconsciously.

According to [4] (13), the reasons someone becomes a smoker is because of curiosity, because they want to be accepted in a certain group, or adventurous value in smoking habits. Another reason is that cigarettes contain a number of symbols that are related to one another such as maturity, virility, habits and even success. This symbol then becomes a psychological attraction for novice smokers.

This research is descriptive analytic with a cross-sectional study design. The data was collected at Aceh Besar Traditional Islamic Boarding School. The population is students who are less than 21 years old, the number of samples is 71 people. Sampling was done by random sampling. Univariate and bivariate analysis with Chi-Square statistical test (significant level $0.05)$ is used as data analysis.

\section{Results and Discussion}

\subsection{Univariate Analysis}

Table 1. Frequency distribution factors related to students' smoking behaviour in Aceh Besar traditional Islamic boarding school in 2018

\begin{tabular}{clll}
\hline NO & \multicolumn{1}{c}{ Descriptions } & Number & \% \\
\hline I & Smoking behavior & & \\
& 1. Smoking & 57 & 80.3 \\
II & 2. Not Smoking & 14 & 19.7 \\
& Level of Education & & \\
& 1. Elementary school & 17 & 23.8 \\
& 2. Junior high school & 27 & 38.1 \\
& 3. Senior high school & 27 & 38.1 \\
III & $\begin{array}{l}\text { Knowledge } \\
\text { 1. Low }\end{array}$ & 53 & 74.6 \\
IV & 2. High & 18 & 25.4 \\
& Cigarettes Availability & & \\
1. Easy & 56 & 78.9 \\
\hline
\end{tabular}




\begin{tabular}{lllc}
\hline NO & \multicolumn{1}{c}{ Descriptions } & Number & \% \\
\hline \multirow{2}{*}{ V } & 2. Hard & 11 & 21.1 \\
& Regulation & & \\
& 1. None & 46 & 64.8 \\
VI & 2. Available & 25 & 35.2 \\
& Smokers' Friend & & \\
& 1. Smoking & 47 & 66.2 \\
& 2. Not smoking & 27 & 33.8 \\
\hline
\end{tabular}

Based on table 1. It can be inferred that the majority of respondents are smokers $(80,3 \%)$, the majority of the junior and senior high school graduated respondents respectively $38.1 \%$, have a limited knowledge on the dangerous of cigarettes (74.6\%). The respondents also state that cigarettes are easy to get in the boarding school environment $(78.9 \%)$. In addition, there are no definite rules about smoking in the school $(64.8 \%)$ and they have close friends who smoke $(66.2 \%)$.

\subsection{Bivariate Analysis}

Table 2. The relationship of education background with the smoking behaviour of students in the traditional Islamic boarding school in Aceh Besar in 2018

\begin{tabular}{|c|c|c|c|c|c|}
\hline \multirow{4}{*}{$\begin{array}{c}\text { Education } \\
\text { Background }\end{array}$} & \multicolumn{4}{|c|}{ Smoking behavior } & \multirow{4}{*}{ P.Value } \\
\hline & \multirow{2}{*}{\multicolumn{2}{|c|}{ Smoking }} & \multirow{2}{*}{\multicolumn{2}{|c|}{$\begin{array}{c}\text { Not } \\
\text { Smoking }\end{array}$}} & \\
\hline & & & & & \\
\hline & $\mathrm{n}$ & $\%$ & $\mathrm{n}$ & $\%$ & \\
\hline Elementary & 15 & 88.2 & 2 & 11.8 & \\
\hline $\begin{array}{l}\text { Junior high } \\
\text { school }\end{array}$ & 21 & 77.8 & 6 & 22.2 & 0.86 \\
\hline \multirow{2}{*}{$\begin{array}{l}\text { Senior } \\
\text { school }\end{array}$} & 21 & 77.8 & 6 & 22.2 & \\
\hline & 57 & & 14 & & \\
\hline
\end{tabular}

Based on above table, it can be seen that the percentage of smoking behaviour can easily be foundin respondents with elementary education $(88.2 \%)$. While the respondents with Junior and senior high school education is just $77.8 \%$.The result of $P$. Value is 0.86 . Therefore, it can be concluded that there is no relationship between level of education and smoking behaviours in traditional Islamic boarding school in Aceh Besar.

Table 3The relationship of students' knowledge on the dangerous of smoking with smoking behaviour in traditional Islamic boarding school in Aceh Besar in 2018

\begin{tabular}{llllll}
\hline \multirow{2}{*}{ Knowledge } & \multicolumn{5}{c}{ Smoking behavior } \\
& $\mathrm{n}$ & $\%$ & $\mathrm{n}$ & $\%$ & \\
& Lot smoking & P.Value \\
How & 45 & 84.9 & 8 & 15.1 & \\
& 12 & 66.7 & 6 & 33.3 & 0.093 \\
& 57 & & 14 & & \\
\hline
\end{tabular}

Based on table 3. Thepercentage of smoking behaviour is higher for those who do not have a knowledge about the dangerous effect of smoking $(84,9 \%)$ as compared to those who have knowledge about the effect of smoking $(66.7 \%)$. The result of P. Value is 0.093 . Therefore, it can be concluded that there is no relation between the knowledge of smoking effect and the smoking behaviour. 
Table 4. The relationship between the availability of cigarettes and the smoking behaviour of traditional Islamic boarding schools in Aceh Besar in 2018

\begin{tabular}{llllll}
\hline \multirow{3}{*}{ Availability of Cigarettes } & \multicolumn{5}{c}{ Smoking behavior } \\
& smoking & \multicolumn{2}{c}{ Not Smoking } & P.Value \\
& $\mathrm{n}$ & $\%$ & $\mathrm{n}$ & $\%$ & \\
\hline Easy & 53 & 94.6 & 3 & 5.4 & \\
Hard & 4 & 27.7 & 11 & 73.3 & 0.000 \\
& 57 & & 14 & & \\
\hline
\end{tabular}

Based on table 4, it can be seen that the percentage of smoking behaviour among respondents who stated that cigarettes were easily obtained in the school environment was $94.6 \%$ compared to respondents who found it difficult to get cigarettes which was only $27.7 \%$. The results of $\mathrm{p}$ value is 0.000 . Therefore, there is a correlation between the availability of cigarettes and smoking behaviour of students in the traditional Islamic boarding school in Aceh Besar.

Table 5. The relationships between regulations and students' smoking behaviour in traditional Aceh Besar Islamic boarding school in 2018

\begin{tabular}{|c|c|c|c|c|c|}
\hline \multirow{3}{*}{ Regulation } & \multicolumn{4}{|c|}{ Smoking Behaviors } & \multirow{3}{*}{ P.Value } \\
\hline & \multicolumn{2}{|c|}{ Smoking } & \multicolumn{2}{|c|}{ Not Smoking } & \\
\hline & $\mathrm{N}$ & $\%$ & $\mathrm{n}$ & $\%$ & \\
\hline Not exist & 43 & 93.5 & 3 & 6.5 & \\
\hline \multirow[t]{2}{*}{ Exist } & 14 & 56 & 11 & 44 & 0.000 \\
\hline & 57 & & 14 & & \\
\hline
\end{tabular}

Based on table 4, it can be seen that the percentage of smoking behaviour among respondents who stated that there is no regulation on smoking in boarding school is $93.5 \%$. While the percentage of respondents who stated that there is a rule in school about smoking is just $56 \%$. The result of P.value is 0.000 . Therefore, there is a relation between regulations and students' smoking behaviour in traditional Aceh Besar Islamic boarding school in 2018.

Table 6. The relationship between friends and students' smoking behaviour in traditional Islamic boarding school in Aceh Besar in 2018

\begin{tabular}{|c|c|c|c|c|c|}
\hline \multirow{3}{*}{ Friend Behavior } & \multicolumn{4}{|c|}{ Smoking behavior } & \multirow{3}{*}{ P.Value } \\
\hline & \multicolumn{2}{|c|}{ Smoking } & \multicolumn{2}{|c|}{ Not Smoking } & \\
\hline & $\mathrm{N}$ & $\%$ & $\mathrm{n}$ & $\%$ & \\
\hline Smoker & 44 & 93.6 & 3 & 6.4 & \\
\hline \multirow[t]{2}{*}{ Not Smoker } & 13 & 54.2 & 11 & 45.8 & 0.000 \\
\hline & 57 & & 14 & & \\
\hline
\end{tabular}

According to the table 6 , it is obvious that the smoking behaviour is higher on respondents who have a smoking friend, which is $93.6 \%$. while the percentage of those who does not have a smoking friend who smoke is only $54.2 \%$. The result of P.value is 0.000 . Therefore, there is a relation between friends and students' smoking behaviour in traditional Aceh Besar Islamic boarding school in 2018.

1. The relationship of education background with the smoking behaviour of students in the traditional Islamic boarding school in Aceh Besar in 2018. 
The results of the study show that the percentage of smoking behaviour, can be encountered more often in respondents with elementary school education background compared to respondents with junior high education and those with senior high school education. Based on the results of statistical tests, it can be concluded that there is no relationship between the level of education with smoking behaviour of students in the traditional Islamic boarding school in Aceh Besar. According to the researchers, this could happen because most of the students had become smokers before they settled in the boarding school environment. In addition, there is no material in the primary and secondary education curriculum that specifically and deeply discusses the dangers of smoking.

According to [4] (13), the reasons someone becomes a smoker is because of curiosity, because they want to be accepted in a certain group, or adventurous value in smoking habits. Another reason is that cigarettes contain a number of symbols that are related to one another such as maturity, virility, habits and even success. This symbol then becomes a psychological attraction for novice smokers.

2. The relationship of students' knowledge on the dangerous of smoking with smoking

behaviour in traditional Islamic boarding school in Aceh Besar

The results show that the percentage of smoking behavior can be encountered more often in respondents who had low knowledge about cigarettes compared to respondents with highknowledge. Based on the results of statistical tests, it can be concluded that there is no relationship between students' knowledge on the dangerous of smoking with smoking behaviour in traditional Islamic boarding school in Aceh Besar. According to the researchers, even though the respondents have had a knowledge about cigarettes, but some other motivating factors would be able to influence someone to continue smoking such as the leader of boarding school who also a smoker and even smoked in the classroom.

Tomkins stated that reasons individuals have smoking behaviour is Habitual (physiological dependence). It is a behaviour that has become a habit. Physically, the individual is addicted to smoking and he cannot resist the internal addiction to smoking. As a result, he must smoke, whether it is during a stressful condition due to problems or in a relaxed condition, it becomes a habit, even a lifestyle.In other words, smoking behaviour in a person, including boarding school students is not because of having high or low knowledge about the dangers of smoking, but because it has become a habit.

Almost everyone knows that smoking can be dangerous to health but there are still many people who ignore their health. Smoking behaviour can be found more often in men than women. Leventhal \& Cleary (in 15) revealed that there are 4 stages of smoking behaviour to become a smoker: the prepatory stage, the initiation stage, the becoming a smoker stage and the Maintenance of Smoking stage. At this stage smoking has become a part of self-regulating. The smokers smoke to get a physiological effect.

3. The relationship between the availability of cigarettes and the smoking behaviour of traditional Islamic boarding schools' students in Aceh Besar

The results show that the smoking behaviour is more common among respondents who state that cigarettes are easily obtained in the boarding school environment compared to respondents who find it is difficult to get cigarettes at the boarding school. Based on the statistical tests, it can be concluded that there is a relation between the availability of cigarettes and the smoking behaviour of traditional Islamic boarding schools' students in Aceh Besar. According to the researchers, this happens because cigarettes can easily be obtained around the surroundings of boarding school, and even sold freely in the boarding school.

[5] (16) classified smokers into two types; active smokers and passive smokers. Active smokers are individuals whose smoking have become a habit. For them, smoking has become part of their life. Those individuals tend to feel anxious and uncomfortable if a day goes without smoking. Therefore, they will try to get it. 
Silvan \& Tomkins (in 17) suggested that based on the Management of Affect Theory, one type of smoker is addictive smoking behaviour. This smoking behaviour is addiction smokers, they tend to increase the dose of cigarettes at any time after the effect of the smoking is gone. Therefore, this type of smokers will always try to get the smoke to fulfill their need

4. The relationships between regulations and students' smoking behaviour in traditional Aceh Besar Islamic boarding school

The results show that the percentage of smoking behaviour is more common among respondents who state that there are no definite rules about smoking in the boarding school environment compared to respondents who state that there are rules. Based on the results of statistical tests, there is a relation between regulations and students' smoking behaviour. According to researchers, in traditional Islamic boarding school in Aceh, there is no binding regulation on smoking bans. Therefore, students can freely smoke anywhere. The researchers did not find any "no smoking" sign in the area of boarding school.

[3] (16) reveal that the factors that cause smoking behaviour is Regulatory factors, which means increasing selling prices or imposing high taxes in order to reduce purchases and consumption of cigarettes. Restrictions on smoking facilities, by setting a non-smoking room / area, are expected to reduce consumption. But in reality, there is an increase in the incidence of starting smoking for students, even though efforts have been made to prevent it.

5. The relationship between friends and students' smoking behaviour in traditional Islamic boarding school in Aceh Besar

The results show that the percentage of smoking behaviour was more common among respondents who have friends who are also smokers compared to respondents who have a nonsmokers friend. Based on the results of statistical tests, there is a relation between friends and students' smoking behaviour in traditional Islamic boarding school in Aceh Besar. According to the researchers, the absence of a ban on smoking and allowing students to smoke in boarding school environment will cause students who do not smoke to be a smoker too.

Smet (19) said that the smoker begins to smoke due to the influence of the social environment. Modelling (imitating the behaviour of others) is one of the determinants in starting smoking behaviour. Lewin (in 20) said that smoking behaviour is a function of the environment and individuals. This means that smoking behaviour is not only caused by internal factors (such as rebellious behaviour and risk taking) but also by environmental factors (such as friends, work environment). According to [6] (21), one of the factors of smoking is due to social factors in the sense that someone smokes because of other people or for the sake of social relationship. [3] (18) reveal the factors that cause smoking behaviour is also Environmental factors. It is related to tobacco usedin family, exposed to tobacco billboards, exposed to artists on tobacco billboards. Tobacco billboards are estimated to have a stronger influence than the influence of parents or peers, this may be because it influences student perceptions of the appearance and benefits of cigarettes.

\section{Thank You Note}

The authors would like to thank the promoters and co-promoters who have guided during the research and preparation of research reports. Special thanks are also addressed to the boarding school leaders, students and all of those who have helped this research.

\section{References}

[1] R. Rosemary, "Antara Motivasi Dan Tantangan Berhenti Merokok (Studi Kasus Mahasiswa Di Banda Aceh )," Komunikologi, vol. 10, no. 1, pp. 9-18, 2013. 
[2] A. . Helgason and K. . Lund, "Environmental tobacco smoke exposure of young children attitudes and health-risk awareness in the Nordic countries," Nicotine Tob. Res., vol. 3, no. 4, pp. 341-345, 2001.

[3] K. Subanada and Suyasa, "Stress, Perilaku Merokok dan Tipe Kepribadian," Pronesis, vol. 6, no. $11,2004$.

[4] T. Y. Aditama, Masalah Merokok dan Penanggulangannya. Jakarta: YP-IDI bekerjasama dengan PDPI dan LM3, 2000.

[5] A. Dariyo, Psikologi Perkembangan Dewasa Muda. Jakarta: PT Gramedia Widiasarana Indonesia, 2003.

[6] Y. . Prabandari, "Pendidikan Kesehatan melalui Seminar dan Diskusi sebagai Alternatif Penanggulangan Perilaku Merokok pada Remaja Pelajar SLTA,” 1994. 